\title{
PR Segment Depression by ECG Finding
}

National Cancer Institute

\section{Source}

National Cancer Institute. PR Segment Depression by ECG Finding. NCI Thesaurus. Code C116135.

An electrocardiographic finding of PR segment depression below the iso-electric line in multiple precordial and/or limb leads. (CDISC) 